\title{
MENENTUKAN MODEL PERTUMBUHAN PENDUDUK PROVINSI SUMATERA BARAT
}

\author{
LINDO FEBDIAN, EFENDI \\ Program Studi Matematika, \\ Fakultas Matematika dan Ilmu Pengetahuan Alam, Universitas Andalas, \\ Kampus UNAND Limau Manis Padang, Indonesia, \\ lindofebdian@yahoo.co.id
}

\begin{abstract}
This research examines the population growth models which is used to estimate the total population of West Sumatra in the future. In this research, we use the secondary data obtained from BPS (Central Bureau of Statistics). The data are population censuses in 1980, 1990, 2000 and 2010. The models in this study are linier model, geometry model, exponential model and logistic model. Based on the results absolute error of the growth models, logistic model with population growth is the best model to project the population of West Sumatra in 2020.
\end{abstract}

Kata Kunci: Population growth model, linear regression model, exponential model, geometry model, logistic model

\section{Pendahuluan}

Model merupakan bentuk abstrak dari dunia nyata. Walaupun belum tentu semua masalah dapat dimodelkan secara matematis, tetapi masalah-masalah itu dapat direduksi dengan asumsi-asumsi yang dikondisikan sehingga dapat dinyatakan dalam bentuk abstrak.

Salah satu aplikasi pemodelan matematika adalah pemodelan pada populasi biologi, baik yang berhubungan dengan populasi manusia maupun hewan atau bakteri. Para ahli telah lama mempelajari permasalahan populasi, khususnya manusia, hewan, dan tumbuhan. Terdapat berbagai macam model populasi spesies tunggal yang kontinu. Kontinu dalam hal ini berarti populasi bergantung waktu tanpa putus. Dari waktu ke waktu bentuk tiap model dimodifikasi sehingga dapat menggambarkan dengan lebih teliti keadaan sebenarnya. Bentuk-bentuk model lain tergantung situasi apa yang akan dianalisis. Dengan adanya model-model populasi ini, memudahkan para ahli untuk dapat memproyeksikan populasi satu spesies pada suatu waktu tertentu, atau menekan laju populasi agar tetap seimbang. Selain model populasi kontinu pada penelitian ini juga menggunakankan model regresi linier sebagai pembanding untuk memproyeksi populasi pada suatu daerah tertentu. Pada penelitian ini data yang diambil adalah data Provinsi Sumatera Barat untuk menentukan model populasi kontinu. 


\section{Model Pertumbuhan Penduduk}

Data yang diperoleh adalah data jumlah penduduk Provinsi Sumatera Barat dari hasil Sensus Penduduk pada tahun 1980, 1990, 2000 dan 2010. Dalam Tabel 1 diberikan data jumlah penduduk Provinsi Sumatera Barat.

Tabel 1. Jumlah Penduduk Provinsi Sumatera Barat(1980 - 2010)

\begin{tabular}{|l|c|}
\hline Tahun & Jumlah Penduduk (jiwa) \\
\hline 1980 & 3.406 .816 \\
\hline 1990 & 4.000 .207 \\
\hline 2000 & 4.248 .931 \\
\hline 2010 & 4.846 .909 \\
\hline
\end{tabular}

Sumber : Data Sensus Penduduk Provinsi Sumatera Barat tahun 1980, 1990, 2000 dan 2010 .

\subsection{Regresi Linier}

Untuk mempermudah penghitungan menentukan model regresi linier dari data pada Tabel 1 maka didapatkan persamaan linier

$$
P(t)=3.440 .365,3+45.690,03 t \text {. }
$$

\subsection{Penyelesaian Model Geometri}

Penghitungan proyeksi jumlah penduduk dengan model geometri, dihitung berdasarkan persamaan geometri yaitu

$$
P(t)=P_{0}(1+r)^{t} .
$$

Berikut akan dicari laju pertumbuhan penduduk untuk tahun 1990-2010 dimana $t=30$ dan $P_{0}=3.406 .816$. Perhatikan persamaan geometri di atas maka

$$
r=0,011821429
$$

dengan menggunakan $r=0,011821429$ maka diperoleh model geometrik

$$
P(t)=3.406 .816(1+0,011821429)^{t} .
$$

\subsection{Penyelesaian Model Eksponensial}

Untuk menentukan model eksponensial dengan data jumlah penduduk Provinsi Sumatera Barat seperti yang tertera pada Table 1, sebelumnya diasumsikan terlebih dahulu bahwa waktu (t) diukur dalam tahun dan populasi awal adalah $\mathrm{P}(0)$, sehingga masalah nilai awal adalah:

$$
\frac{d P}{d t}=k P,
$$

dan solusi dari persamaan diatas adalah : 


$$
P(t)=P(0) \cdot e^{k t}
$$

Perhatikan persamaan di atas, dengan menggunakan metode dalam persamaan diferensial maka diperoleh

$$
\ln P(t)=\ln P(0)+k t
$$

Dengan demikian didapatkan model eksponensial

$$
P(t)=e^{0,011180105 t+15,0570922}
$$

atau

$$
\ln P(t)=0,011180105 t+15,0570922 .
$$

\subsection{Penyelesaian Model Logistik}

Berdasarkan Tabel 1 di atas mengenai data penduduk Provinsi Sumatera Barat menurut hasil Sensus Penduduk antara tahun 1980 hingga 2010, peneliti melakukan simulasi model pertumbuhan penduduk dengan menggunakan persamaan logistik sebagai berikut

$$
P(t)=\frac{P_{0} K e^{r t}}{e^{r t} P_{0}-P_{0}+K}
$$

Substitusi nilai $K=60.789 .882$ jiwa dan $P_{0}=3.406 .816$ jiwa ke solusi persamaan logistik di atas maka diperoleh solusi persamaan logistik sebagai berikut :

$$
P(t)=\frac{60.789 .882}{1+16,843605877 \cdot e^{-r t}}
$$

(a) Pertumbuhan Populasi

Berikut ini adalah Tabel 2 yang menyatakan perkiraan laju pertumbuhan relatif pada model logistik : Dari Tabel 2 dapat dilihat bahwa laju per-

Tabel 2. Laju pertumbuhan penduduk Provinsi Sumatera Barat.

\begin{tabular}{|l|c|c|}
\hline Tahun & Jumlah Penduduk & $\mathrm{r}$ \\
\hline $1980-1990$ & 4.000 .207 & 0,017096269 \\
\hline $1990-2000$ & 4.248 .931 & 0,011783668 \\
\hline $2000-2010$ & 4.846 .909 & 0,012599315 \\
\hline
\end{tabular}

tumbuhan penduduk tahun 1980-2000 mengalami penurunan sekitar 0,56 persen dari tahun 1980-1990 dan relatif tetap pada tahun 1980-2010. Kita dapat menentukan model yang lebih baik dengan menggunakan data pada Tabel 2 untuk memperkirakan berapa laju pertumbuhan relatif terhadap pertumbuhan jumlah penduduk. Dengan nilai $r$ pada tahun 1980-2010 diperoleh persamaan pertumbuhan logistik dengan $K=60.789 .882$ jiwa yaitu

$$
P(t)=\frac{60.789 .882}{1+16,843605877 . e^{-0,012599315 t}}
$$


(b) Regresi Logistik

Perhatikan persamaan logistik sebelumnya, dengan menggunakan metode dalam persamaan diferensial maka diperoleh

$$
\ln \left|\frac{P(t)}{P(t)-K}\right|=r t+c, \quad \text { c konstanta. }
$$

Untuk menentukan model logistik dengan regresi logistik maka diperoleh persamaan yaitu

$$
\ln \left|\frac{P(t)}{P(t)-60.789 .882}\right|=0,011986491 t-2,807614592 .
$$

\subsection{Perbandingan Hasil Estimasi Model-Model Pertumbuhan Penduduk}

Berikut ini adalah Tabel 3 yang menyajikan perbandingan jumlah penduduk hasil sensus dengan hasil model regresi linier, model geometri, model eksponensial dan

\begin{tabular}{|c|c|c|c|c|c|c|}
\hline \multicolumn{7}{|c|}{$\begin{array}{l}\text { Tabel 3. Hasil Estimasi Penduduk Provinsi Sumatera Barat dengan Model-Model } \\
\text { Pertumbuhan Penduduk. }\end{array}$} \\
\hline \multirow[b]{2}{*}{ Tahun } & \multirow[b]{2}{*}{$\begin{array}{c}\text { Hasil } \\
\text { Sensus }\end{array}$} & \multicolumn{5}{|c|}{ Hasil Estimasi Model } \\
\hline & & $\begin{array}{l}\text { Model } \\
\text { Linier }\end{array}$ & $\begin{array}{c}\text { Logistik } \\
\text { (pertumbuhan } \\
\text { populasi) }\end{array}$ & $\begin{array}{l}\text { Logistik } \\
\text { (regresi } \\
\text { logistik) }\end{array}$ & Eksponensial & $\begin{array}{l}\text { Metode } \\
\text { Geometrik }\end{array}$ \\
\hline 1980 & 3.406 .816 & 3.440 .365 & 3.406 .816 & 3.459 .800 & 3.461 .083 & 3.406 .816 \\
\hline 1990 & 4.000 .207 & 3.897 .266 & 3.835 .402 & 3.872 .322 & 3.870 .496 & 3.831 .664 \\
\hline 2000 & 4.248 .931 & 4.354 .166 & 4.313 .853 & 4.330 .314 & 4.328 .338 & 4.309 .493 \\
\hline 2010 & 4.846 .909 & 4.811 .066 & 4.846 .909 & 4.837 .870 & 4.840 .339 & 4.846 .909 \\
\hline
\end{tabular}
model logistik.

Gambar 1. Model regresi linier, model geometri, model eksponensial dan model logistik

Dari model yang didapat akan dipilih sebuah model terbaik dengan menentukan $\bar{\varepsilon}$ yang terkecil. Berikut ini adalah Tabel 4 yang menyajikan hasil $\bar{\varepsilon}$ model regresi linier, model geometri, model eksponensial dan model logistik

Model geometri dan model logistik dengan pertumbuhan populasi pada Tabel 4 memiliki $\bar{\varepsilon}$ yang lebih kecil dari model logistik dengan dengan regresi logistik, model regresi linier dan eksponensial sehingga bisa digunakan untuk memproyeksi jumlah penduduk Provinsi Sumatera Barat pada Sensus Penduduk 2020. Prediksi jumlah penduduk Provinsi Sumatera Barat pada tahun 2020 berdasarkan hasil model geometri sebesar 5.451.344 jiwa. Pada model logistik dengan pertumbuhan populasi, diprediksi jumlah penduduk Provinsi Sumatera Barat pada tahun 2020 sebesar 5.439.490 jiwa. 
Model geometri tidak realistik lagi jika dipakai dalam jangka waktu yang cukup lama. Dengan demikian model yang dipakai untuk estimasi pada penelitian ini yaitu model logistik dengan pertumbuhan populasi.

\section{Kesimpulan}

Berdasarkan pembahasan yang telah diuraikan sebelumnya, maka dapat disimpulkan bahwa model pertumbuhan yang akurat untuk pertumbuhan penduduk Provinsi Sumatera Barat adalah model logistik dengan pertumbuhan populasi. Berdasarkan data hasil Sensus Penduduk 1980, 1990, 2000 dan 2010 model pertumbuhan itu dinyatakan dalam persamaan $P(t)=\frac{60.789 .882}{1+16.843605877 . e^{-0,012599315 t}}$. Proyeksi jumlah penduduk Provinsi Sumatera Barat pada tahun 2020 berdasarkan hasil model tersebut adalah diperkirakan 5.439.490 jiwa. Keakuratan hasil proyeksi ini dapat diketahui nanti pada Sensus Penduduk tahun 2020.

\section{Ucapan Terima kasih}

Penulis mengucapkan terima kasih kepada Bapak Efendi, M.Si, Bapak Zulakmal, M.Si, Bapak Bukti Ginting, M.Si dan Bapak Dr. Ahmad Iqbal Baqi yang telah memberikan masukan dan saran sehingga paper ini dapat disusun dengan baik.

\section{Daftar Pustaka}

[1] Adioetomo, Sri Moertiningsih dan Omas Bulan Samosir. 2010. Dasar-Dasar Demografi. Edisi kedua. Salemba Empat, Fakultas Ekonomi Universitas Indonesia.

[2] Jannah, Arina Firdausil. 2008. Analisis Persamaan Diferensial Model Populasi Kontinu untuk Spesies Tunggal. (http://lib.uin-malang.ac.id. Diakses 3 Juni 2013).

[3] Katalog BPS. 2012. Kabupaten Sumatera Barat Dalam Angka 2012. Sumatera Barat : BPS Sumatera Barat.

[4] Murray, J.D. 2002. Matematical Biology 1 An Introduction, 3rd Edition. New York: Springer.

[5] Purcell, Edwin J., Dale Varberg and Steven E. Rigdon. 2004. Kalkulus Edisi Kedelapan. Terjemahan oleh I Nyoman Susila. Bandung: Erlangga.

[6] Stewart, James. 2003. Kalkulus Edisi ke-4 Jilid 2. Jakarta : Erlangga. 